\title{
The profitability analysis of rubber plantation in Batang Hari Regency and Sanggau Regency (Case study: Penerokan Village and Semoncol Village)
}

\author{
Fajri Shoutun $\mathrm{Nida}^{1,2^{*}}$, and Tri Bastuti Purwantini ${ }^{2}$ \\ ${ }^{1}$ Department of Agricultural Socio-Economics, Faculty of Agriculture, Universitas Gadjah Mada, Jl. \\ Flora Bulaksumur Sleman 55281, Yogyakarta, Indonesia \\ ${ }^{2}$ Indonesian Center for Agricultural Socioeconomic and Policy Studies (ICASEPS), Ministry of \\ Agriculture, Jl. Tentara Pelajar No. 3B Bogor 16124, West Java, Indonesia
}

\begin{abstract}
During 2009-2012 the price of rubber increased sharply, on the contrary during 2012-2018 the price decreased, and the farm price level in 2018 was lower than the average in 2009. The decline in rubber prices had an impact on the income of rubber farming. This study aims to analyze the changes in rubber prices on the performance of rubber farming and rubber farmers' incomes The main data used is the ICASEPS' Patanas database for 2009, 2012, and 2018. This study took cases in small-holder farmer in Penerokan Village (Batang Hari Regency, Jambi) and Semoncol Village (Sanggau Regency, West Kalimantan). Data analysis using R/C ratio. The results showed that the average price of rubber during 2009-2012 increased from IDR7,961/kg to IDR12,968/kg or increased by $62.9 \%$, but in 2018 its decreased by an average of $45 \%$ to IDR6,875/kg and tended to decrease. Revenue from rubber farming during 2009, 2012 and 2019 in Penerokan was IDR12,974,000 respectively; IDR10,843,000 and IDR7,878,000 with an $\mathrm{R} / \mathrm{C}$ ratio of $1.67 ; 1.87$ and 1.67. Revenue from rubber farming in Semoncol 2009, 2012 and 2019 was IDR 10,656,000 respectively; IDR15,990,000 and IDR10,950,000 with an $\mathrm{R} / \mathrm{C}$ ratio of $1.50 ; 2.00$ and 1.29 . The $\mathrm{R} / \mathrm{C}$ ratio of rubber farming in both villages is more than 1 , indicating that rubber farming is economically feasible. Household income in both locations still dominated by agricultural activities.
\end{abstract}

Keywords: rubber price, small-holder, profitability, R/C ratio

\section{Introduction}

Rubber has an important role in the Indonesian economy. It is also one of Indonesia's large export commodities as a source of foreign exchange besides oil and gas. The total export value of Indonesian natural rubber was USD3,527,202 in 2019 [1] making Indonesia the world's second-largest rubber country.

\footnotetext{
* Corresponding author: fajrishoutunnida@gmail.com
} 
World rubber prices fluctuated during 2007-2018 (Figure 1). The price started to increase in 2009 and peaked in 2011 and then the price decreased until now. The increase in rubber price occurred due to a gap between the limited supply of natural rubber and an increase in demand [2]. The declining price after 2011 was due to increased production from rubberproducing countries causing oversupply in the world market [3].

The contribution of rubber to the Indonesian economy has not been well managed so that it has not contributed to national development in improving the standard of living, especially for rubber farmers [4]. These conditions specified before affecting the income of smallholder rubber plantations, which are the largest rubber producers in Indonesia. Almost $90 \%$ of rubber production in Indonesia was produced by smallholder rubber plantations [5].

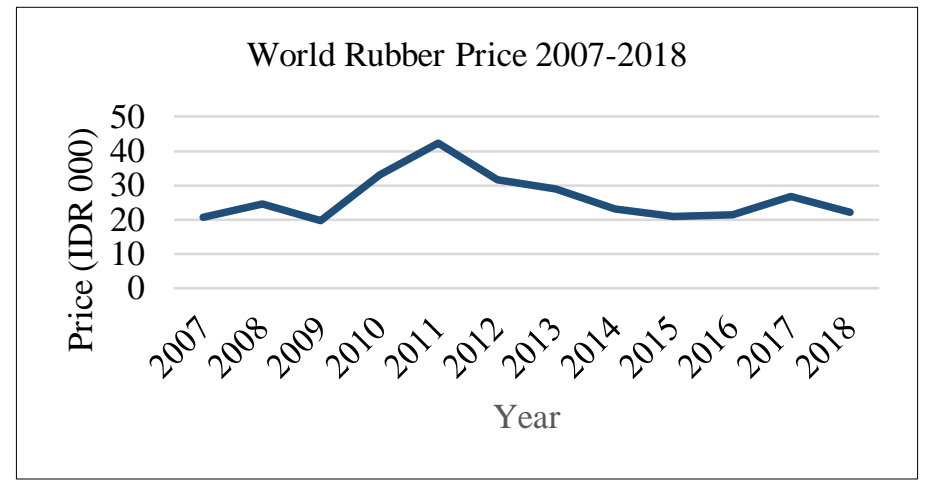

Fig. 1. World Rubber Price 2007-2018 [6]

\section{Data and methods}

The data that been used in this paper was the ICASEPS' Panel Petani Nasional (Patanas) database that was collected in 2009, 2012, and 2018, based on the previous year's farming condition. The selection period years was based on the existence of Patanas household surveys that were conducted in rubber agro-ecosystem locations. The data was panel data of 40 household in Patanas' survey location in Penerokan Village (Batang Hari Regency, Jambi) and Semoncol Village (Sanggau Regency, West Kalimantan).

The rubber farmer income was defined by the difference between total revenue and total cost [7]

$$
\pi=T R-T C
$$

The estimation of rubber farming profitability described by the Revenue Cost ratio [7] as shown below:

$$
R / C=T R / T C
$$

\section{Results and discussions}

\subsection{Characteristic of the rubber farming}

\subsubsection{Land managed}

The area is managed by farmers affecting the production of tapped rubber. The increasing area that is managed by farmers for rubber plantation the more plants that can be cultivated. The increase in the number of rubber plants can affect the production of rubber latex. The land tenure of rubber farmers in Penerokan and Semoncol Villages was shown in Table 1. 
Table 1. Average land tenure by rubber farmers in Penerokan and Semoncol Village

\begin{tabular}{|l|r|r|r|r|r|}
\hline \multirow{2}{*}{ Village } & \multicolumn{3}{|c|}{ Land tenure (ha) } & \multicolumn{2}{c|}{ Growth(\%/yr) } \\
\cline { 2 - 7 } & 2009 & 2012 & \multicolumn{1}{c|}{2018} & $2009-2012$ & $2012-2018$ \\
\hline Penerokan & 2.69 & 5.36 & 4.97 & 33.09 & -1.21 \\
\hline Semoncol & 3.53 & 4.52 & 3.81 & 9.35 & -2.62 \\
\hline Average & 3.11 & 4.94 & 4.38 & 19.61 & -1.89 \\
\hline
\end{tabular}

Source: Patanas 2009, 2012, 2018

Farmer's land tenure generally increased between 2009-2012. The increase in land tenure in sample villages in the period 2009-2012 was caused by the activities of clearing new plantations from forest lands that originally had not been cultivated, purchases land from other farmers, and converts rice fields and moorlands into rubber plantations [8]. This pattern is closely related to the level of farm productivity achieved and the price level received by farmers. The increase in land for rubber plantations was triggered by the increase in the price of natural rubber on the world market which had a major impact on the interest of farmers in cultivating rubber plants. However, between 2012-2018 there was a decrease in land tenure. The decline in land tenure was triggered by a decline in world rubber prices and the conversion of rubber smallholders to oil palm plantations. Various factors that influence the land conversion are economic aspects, environmental and technical aspects, but the dominant factor is the economic factor considering that the income from the oil palm business is higher than the rubber plantation business [9].

\subsubsection{Rubber age and producing stage}

Rubber plants generally have an immature period of five years and can begin to be tapped at the beginning of the sixth year. Economically, rubber plants can be tapped for 15 to 20 years. The yield of rubber tapping is influenced by the age of the plant [10].

The field finding showed that the average age of rubber plants in the research locations in 2009, 2012, and 2018 was 19-20 years, 22-23 years, and 28 years. Based on the stages of rubber production, rubber plants are divided into three stages of production, namely immature (IP) $<5$ years of age, mature plants (MP) of 6-25 years of age, and damaged or aging (DP) plants of $<25$ years of age. The percentage of rubber-producing plants in Penerokan and Semoncol villages is shown in Figure 2 and Figure 3. Rubber cultivated by farmers is dominant at the production stage.

The older the rubber plant, the higher the yield until it reaches its peak productive age and then gradually decreases, but this also depends on the intensity of treatment as well. Under normal conditions, the optimal productivity of rubber is between 25-30 years, after 30 years, the latex produced by rubber is decreased. Conditions in 2018 showed around $11.6 \%$ in Penerokan and $14.7 \%$ in the damaged or unproductive category, however, during 2009-2018 the number of non-productive plants tended to decrease, which indicates rubber rejuvenation, especially found in Semoncol Village. In contrast to the case in Penerokan Village, the dynamics of crop change resulted in an increasing percentage (Figure 2). 


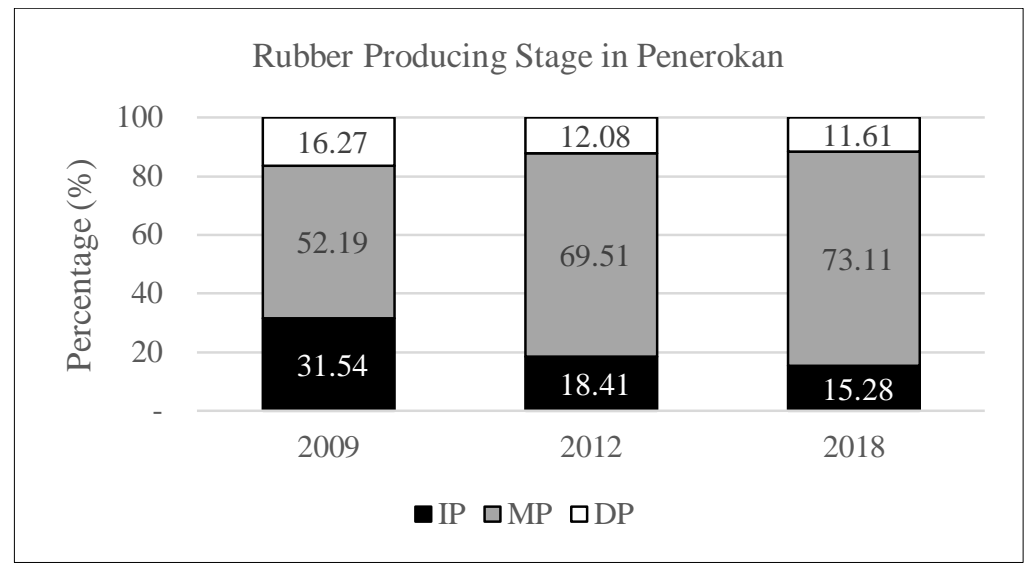

Fig. 2. Rubber producing stage in Penerokan Village 2009-2018

Based on the age of the rubber plants cultivated, it is still dominated by plants with productive categories, but in the last ten years, rubber plantations have not been well maintained and attacked by fungi so that productivity is low [11]. Farmers are not enthusiastic about maintaining good rubber because the selling price of latex rubber is relatively low due to the low price of natural rubber in the global market. With rubber planting conditions, farmers must be more intensive in maintaining their plants, the rejuvenation of rubber plants was limited due to the low capital that farmers had and difficulties in obtaining superior clone rubber seeds. Some farmers do natural rejuvenation using fallen seeds that grow by themselves. Usually, farmers select seeds with good growth performance for rejuvenation and seeds with poor performance are not planted.

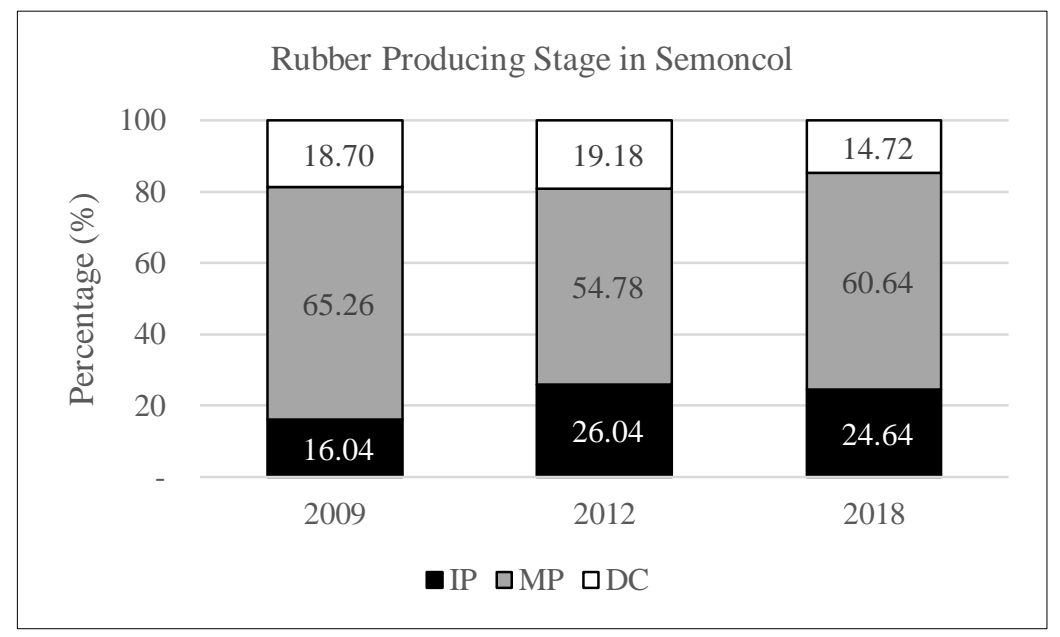

Fig. 3. Rubber producing stage in Semoncol Village 2009-2018

\subsection{Revenue and cost of rubber farming}

Revenue that farmers received was determined by the production of rubber and the rubber price. The form of rubber production in both locations was in form of a slab with a dry content of around $35-40 \%$. The cost has consisted of input (seed, fertilizer, pesticide, and other input) and labor that has been used to maintain the rubber plantation and tapping rubber sap. 
Profitability is determined by the amount of revenue and costs to carry out farming activities. Simple parameters to measure farm profitability can be seen from the $\mathrm{R} / \mathrm{C}$ ratio. It is calculated the ratio between revenue to costs, farming is said to be economically feasible if the value of $\mathrm{R} / \mathrm{C}>1$.

Table 2. Revenue and cost of rubber farming in Penerokan Village Batang Hari, Jambi

\begin{tabular}{|c|c|c|c|}
\hline Description & 2009 & 2012 & 2018 \\
\hline Revenue (IDR 000) & 12,974 & 20,260 & 19,350 \\
\hline - Production $(\mathrm{kg})$ & 1,580 & 2,148 & 1,967 \\
\hline - Price (IDR/kg) & 8,205 & 9,440 & 9,840 \\
\hline - Side Production (IDR 000) & 0 & 0 & 0 \\
\hline \multicolumn{4}{|l|}{ Production Cost } \\
\hline - Input (labor excluded) (IDR 000) & 516 & 685 & 712 \\
\hline$(\%)$ & 6.66 & 7.27 & 6.21 \\
\hline - Labor (IDR 000) & 6,980 & 8,240 & 9,350 \\
\hline$(\%)$ & 90.16 & 87.5 & 81.5 \\
\hline - Other (IDR 000) & 246 & 492 & 1.41 \\
\hline$(\%)$ & 3.18 & 5.23 & 12.29 \\
\hline Total Cost (Rp000) & 7,742 & 9,417 & 11,472 \\
\hline Profitability (IDR 000) & 5,232 & 10,843 & 7,878 \\
\hline $\mathrm{R} / \mathrm{C}$ & 1.67 & 1.87 & 1.67 \\
\hline
\end{tabular}

Revenue and cost of rubber farming in Penerokan Village Batang Hari Regency Jambi was shown in Table 1. The highest revenue that farmers received was in 2012, marking at around twenty million rupiahs. The price that the farmer received was fluctuating between IDR8,205 and IDR9,840. the price difference at the farmer's price level is much lower than the world price in the year concerned. In a row, the share of prices at the farm level in 2009 , 2012, and 2018 in Penerokan village compared to world prices of 58.26\%; 70.12\%; 55.73\%

Table 3. Revenue and cost of rubber farming in Semoncol Village Sanggau, West Kalimantan, 2009, 2012 and 2018

\begin{tabular}{|c|c|c|c|}
\hline Description & 2009 & 2012 & 2018 \\
\hline Revenue (IDR 000) & 10,656 & 15,990 & 10,950 \\
\hline - Production $(\mathrm{kg})$ & 1,395 & 1,786 & 1,480 \\
\hline - Price (IDR/kg) & 7,635 & 8,930 & 7,340 \\
\hline - Side Production (IDR 000) & 68 & 133 & 6 \\
\hline \multicolumn{4}{|l|}{ Production Cost } \\
\hline - Input (labor excluded) (IDR 000) & 236 & 525 & 727 \\
\hline$(\%)$ & 3.32 & 6.57 & 8.58 \\
\hline - Labor (IDR 000) & 6,695 & 7,150 & 7,560 \\
\hline$(\%)$ & 94.24 & 89.46 & 89.27 \\
\hline - Other (IDR 000) & 173 & 317 & 182 \\
\hline$(\%)$ & 2.44 & 3.97 & 2.15 \\
\hline Total Cost (Rp000) & 7,104 & 7,992 & 8,469 \\
\hline Profitability (IDR 000) & 3,552 & 7,998 & 2,481 \\
\hline $\mathrm{R} / \mathrm{C}$ & 1.5 & 2 & 1.29 \\
\hline
\end{tabular}

Revenue and cost of rubber farming in Semoncol Village Sanggau Regency West Kalimantan was shown in Table 2. The highest revenue that farmers received was also in 2012, marking at around fifteen million rupiahs. The price that the farmer received was fluctuating between IDR7,304 and IDR8,930. The farmer's price level was lower than the world price in the respective year and almost similar to the farmer in Penerokan Village. The farmer price level in 2009, 2012, and 2018 in Semoncol village were lower than the world price by $61.17 \% ; 71.74 \% ; 66,90 \%$. 
One of the factors that cause differences in prices at the farm level and world prices is the different forms of the product. At the farmer level, the rubber form was a slab with a dry content of $35-40 \%$ while the price in the world market was for the rubber in the dry slab form. In both locations showed that the dominant cost of rubber farming was the labor cost. The labor cost was around $90 \%$ of the total cost It showed that the using of the input such as fertilizer and pesticide to maintain the rubber crops were minimum that only around 6-7\% from the total cost.

The $\mathrm{R} / \mathrm{C}$ ratio in the survey period was always more than one in both locations. This amount is almost the same as the results of research in the Bungo Jambi Regency [12]. This shows that rubber farming continues to provide benefits for farmers despite fluctuations in the prices they receive. The highest $\mathrm{R} / \mathrm{C}$ ratio was in Semoncol Village in 2012. It shows that the revenue of rubber farming was doubled compared to the cost. In 2018 the $\mathrm{R} / \mathrm{C}$ ratio was lower than in 2012 for both locations. It was indicating that the declined price of rubber affecting the farmer profitability in 2018. The result of research in Jambi province [13] shows that rubber farmers in the region have not been efficient in allocating inputs and their production has not been optimal, so the welfare of farmers is relatively low,

\subsection{Role of rubber farming in household income}

Farmer household income in Penerokan Village and Semoncol Village consists of agricultural and non-agricultural sectors. The highest income in the agricultural sector is income from plantation land agriculture, in this case, rubber farming activities. Income from rubber farming in 2018 reached $43.7 \%$, this is much lower than the conditions in $2009(55 \%)$ and $2012(69 \%)$. The dominance of the source of income from rubber farming is because this business is the main income that households rely on by land-managed tenure and rubber plantation conditions. Rubber plants can be harvested almost every day (except the rainy season) and sold every two weeks so that farmers can get cash quickly and relatively easily in terms of selling rubber latex products.

The rubber plantation system is generally a monoculture system so that there is a risk of falling prices and no other crop opportunities. The results of research in a region of India and Thailand [14] show that a monoculture system of rubber can be implemented, provided that prices remain profitable and the primary market is efficient. Further findings indicate the dominant contribution of rubber production to the gross household income of rubber farmers in an integrated farming system. Meanwhile, the results of research in the Mekong region, China show that rubber cultivation always has a significant and positive effect on food diversity, it also has an indirect impact on food diversity through two channels, namely agricultural production diversity and household income. A series of heterogeneous analyzes revealed that rubber cultivation contributes more to household food diversity for small farmers who have relatively low household wealth or live in villages without markets [15]. The cultivation of agricultural commodity crops around the rubber plantations in the research location is expected to contribute to household income and household food consumption.

In addition to agricultural household income, farmers also earn non-agricultural income with a contribution of around 39\%, this amount is quite large compared to the conditions in $2009(22.8 \%)$ and $2012(24.7 \%)$. The increasing contribution of the non-agricultural sector, especially the contribution of household members' income, especially young people who migrate to cities and work in non-agriculture, was relatively less in the previous period. Considering that the dominance of household income comes from rubber farming, price fluctuations, and rubber farming income affect the total household income. It appears that nominal income in 2012, is the highest (Table 3) compared to income in 2009 and 2018. Likewise for real income, which is calculated using the average local medium rice price deflator. In 2012 household income was equivalent to $5846 \mathrm{Kg}$ of rice, while in 2009 income 
was equivalent to $3067 \mathrm{Kg}$ of rice and in 2018 it was equivalent to $3480 \mathrm{Kg}$ of rice. Fluctuations in rubber prices greatly affect household income and also affect rubber business management. When prices are high, farmers tend to take good care of their plants and vice versa.

Table 4. Total income of households in Penerokan Village Batang Hari Regency, Jambi dan Semoncol Village Sanggau Regency, West Kalimantan

\begin{tabular}{|l|r|r|r|r|r|r|}
\hline \multirow{2}{*}{ Source of income } & \multicolumn{2}{|c|}{2009} & \multicolumn{2}{|c|}{2012} & \multicolumn{2}{c|}{2018} \\
\cline { 2 - 7 } & IDR (000) & $\%$ & IDR (000) & $\%$ & IDR (000) & $\%$ \\
\hline A. Agriculture & & & & & & \\
\hline 1. Farming & & & & & & \\
\hline a. Rice-field land & 2,079 & 10.09 & 2,214 & 4.58 & 3,248 & 7.78 \\
\hline b. Moor land & 734 & 3.56 & 0 & 0.00 & 0 & 0 \\
\hline c. Estate land & 11,346 & 55.07 & 32,899 & 68.09 & 18,240 & 43.69 \\
\hline d. Yard & 0 & 0.00 & 0 & 0.00 & 173 & 0.41 \\
\hline d. Ruminant & 150 & 0.73 & 3,475 & 7.19 & 332 & 0.79 \\
\hline e. Poultry & 0 & 0.00 & 6,057 & 12.54 & 9 & 0.02 \\
\hline g. Pond & 0 & 0.00 & 0 & 0.00 & 39 & 0.09 \\
\hline 2. Agriculture labor & 1,598 & 7.76 & 1,025 & 2.12 & 1,052 & 2.52 \\
\hline 3. Agriculture asset renting & 0 & 0.00 & 0 & 0.00 & 2,178 & 5.22 \\
\hline Sub Total & 15,907 & 77.20 & 36,282 & 75.09 & 25,270 & 60.54 \\
\hline B. Non-agriculture & & & & & & \\
\hline 1. Industry & 402 & 1.95 & 12 & 0.02 & 600 & 1.44 \\
\hline 2. Labor in the construction sector & 500 & 2.43 & 3,022 & 6.25 & 168 & 0.40 \\
\hline 3. Labor in the transportation sector & 0 & 0.00 & 0 & 0.00 & 0 & 0.00 \\
\hline 4. Trading & 1,094 & 5.31 & 5,332 & 11.04 & 1,179 & 2.82 \\
\hline 5. Labor in other sectors & 293 & 1.42 & 4,950 & 10.24 & 446 & 1.07 \\
\hline 6. Governance & 0 & 0.00 & 0 & 0.00 & 6,043 & 14.48 \\
\hline 7. Remittance & 75 & 0.36 & 2,135 & 4.42 & 596 & 1.43 \\
\hline 8. Non-agriculture labor & 2,200 & 10.68 & 18,918 & 39.15 & 2,381 & 5.70 \\
\hline 9. Other & 133 & 0.65 & 11,001 & 22.77 & 5,061 & 12.12 \\
\hline Sub Total & 4,697 & 22.80 & 12,035 & 24.91 & 16,474 & 39.46 \\
\hline TOTAL & 20,604 & 100 & 48,317 & 100 & 41,744 & 100 \\
\hline Total Equivalent Of Rice (Kg) & 3.067 & & 5.846 & & 3480 & \\
\hline
\end{tabular}

\section{Conclusion}

The fluctuation of rubber price fluctuations has an impact on rubber farming income and also affects the intensity of rubber farming management. The results of the $\mathrm{R} / \mathrm{C}$ ratio in the two villages show that smallholder rubber plantations are still economically feasible for farmers to cultivate, even though the profits are decreasing from 2012-2018.

Household income in both locations is still dominated by agricultural activities, especially rubber farming. With the decreasing income of rubber farming, household income also tends to decrease, so that price fluctuations affect fluctuations in household income, both nominal and real income equivalent to rice.

We would like to thank the ICASEPS Patanas Team for allowing us to use the research data and the ICASEPS Database Team who helped process the data. 


\section{References}

1. Trade Map. List of importers for the selected product 2020. [Online] from https://www.trademap.org/Country_SelProduct_TS.aspx?nvpm=1\%7c\%7c\%7c\%7c \%7c4001\%7c\%7c\%7c4\%7c1\%7c1\%7c1\%7c2\%7c1\%7c2\%7c1\%7c\%7c1 (2020) [Accesed on February 11, 2021].

2. C. W. Su, L. Liu, R. Tao, O. R. Lobont. Agricultural Economics-Czech. 65,2:67-73 (2019). https://www.agriculturejournals.cz/publicFiles/151_2018AGRICECON.pdf or https://doi.org/10.17221/151/2018-AGRICECON

3. K. A. Nyantakyi, B. L. Peiris, L. H. P. Gunaratne. International Journal of Development and Sustainability. 4,5:492-504(2015). https://isdsnet.com/ijds-v4n51.pdf

4. Y. Erlina, D. Koestiono, N. Hanani, Syafrial. Was Transactions On Business And Economics.

16:130-137(2019). https://www.wseas.org/multimedia/journals/economics/2019/a225107-704.pdf

5. [BPS] Statistics Indonesia. Indonesian rubber statistics 2019. [Online] from https://www.bps.go.id/publication/download.html?nrbvfeve=YmJlMDkxNGJhZD Q1YzY0Yzg3YzAwNWZi\&xzmn=aHR0cHM6Ly93d3cuYnBzLmdvLmlkL3B1Y mxpY2F0aW9uLzIwMjAvMTEvMzAvYmJlMDkxNGJhZDQ1YzY0Yzg3YzAw NWZiL3N0YXRpc3Rpay1rYXJldC1pbmRvbmVzaWEtMjAxOS5odG1s\&twoadf noarfeauf=MjAyMS0wNS0wNSAxMzozMzo0Ng\%3D\%3D (2020). [Accesed on February 11, 2021].

6. Indexmundi. Rubber monthy price - rupiah per kilogram. [Online] from https://www.indexmundi.com/commodities/?commodity=rubber\&months=180\&cu rrency=idr (2019). [Accesed on April 3 2021].

7. Soekartawi. Analisis usahatani. Universitas Indonesia Press (1995).

8. S.H. Sulilowati, T.B. Purwantini, D. Hidayat, M. Maulana, A.M. Ar-rozi, R.D. Yofa, Supriyati, W.K. Sejati. Panel Petani Nasional (PATANAS): Dinamika indikator pembangunan pertnian dan perdesaan di wilayah agroekosistem lahan kering berbasis perkebunan in Research report. Indonesian Center for Agricultural Socioeconomic and Policy Studies (2012). (Unpublised).

9. A.Y. P Hasibuan, Khairunnisyah, D. Hendrawan. AGRILAND Jurnal Ilmu Pertanian 8,2:149-157(2020). https://jurnal.uisu.ac.id/index.php/agriland/article/view/3080 or https://doi.org/10.30743/agr.v8i2.3080

10. D. Ulfah, Gt. A.R. Thamrin, T. W. Natanael. Jurnal Hutan Tropis 3,3: 247-252 (2015). https://ppjp.ulm.ac.id/journal/index.php/jht/article/download/2276/1995

11. Saptana, T.B. Purwantini, Sunarsih, C. Muslim, H. Supriadi. A.M. Zakaria. Panel Petani Nasional: Dinamika indikator pembangunan pertanian dan perdesaan di wilayah agroekosistem lahan kering berbasis perkebunan in Research report. Indonesian Center for Agricultural Socioeconomic and Policy Studies (2018). (Unpublised).

12. J. Ali, A. Delis, S. Hodijah. Jurnal Perspektif Pembiayaan dan Pembangunan Daerah 2,4:201-208(2015). https://online-journal.unja.ac.id/JES/article/view/2616 or DOI: https://doi.org/10.22437/ppd.v2i4.2616

13. Kuswanto, Z. Alamsyah, Armandelis, Zulfanetty. International Journal of Economics and Financial Issues, 9,2:80-86(2019). https://www.econjournals.com/index.php/ijefi/article/download/7503/pdf or DOI: https://doi.org/10.32479/ijefi.7503

14. P.K. Viswanathan. Asian J. of Agriculture and Development 5,2:1-19(2008). https://core.ac.uk/download/pdf/6231836.pdf 
15. Y. Luo, S. Min, J. Bai. Food Energy Secur. 00:e285. :1-21(2021). https://onlinelibrary.wiley.com/doi/full/10.1002/fes3.285 or DOI: 10.1002/fes3.285 